\title{
Ascorbic Acid Inhibits Liver Cancer Growth and Metastasis in vitro and in vivo, Independent of Stemness Gene Regulation
}

\author{
Jingjing Wan ${ }^{1 \dagger}$, Juan $\mathrm{Zhou}^{2 \dagger}$, Lu Fu${ }^{2 \dagger}$, Yubin $\mathrm{Li}^{2}$, Huawu Zeng ${ }^{2}$, Xike $\mathrm{Xu}^{2}$, Chao $\mathrm{Lv}^{3 *}$ and \\ Huizi Jin $^{1 *}$ \\ ${ }^{1}$ School of Pharmacy, Shanghai Jiao Tong University, Shanghai, China, ${ }^{2}$ School of Pharmacy, Naval Medical University, \\ Shanghai, China, ${ }^{3}$ Institute of Interdisciplinary Integrative Medicine Research, Shanghai University of Traditional Chinese \\ Medicine, Shanghai, China
}

OPEN ACCESS

Edited by:

Wei Peng,

Chengdu University of Traditional

Chinese Medicine, China

Reviewed by:

$X$ in $X u$,

Chinese Academy of Medical

Sciences, China

Dongwei Zhang,

Beijing University of Chinese Medicine,

China

${ }^{*}$ Correspondence:

Huizi Jin

kimhz@sjtu.edu.cn

Chao LV

Ivchaoanhui@163.com

${ }^{\text {t}}$ These authors have contributed equally to this work

Specialty section: This article was submitted to Pharmacology of Anti-Cancer Drugs,

a section of the journal

Frontiers in Pharmacology

Received: 16 June 2021

Accepted: 12 August 2021

Published: 24 August 2021

Citation:

Wan J, Zhou J, Fu L, LiY, Zeng H, XuX, Lv C and Jin H (2021) Ascorbic Acid Inhibits Liver Cancer Growth and

Metastasis in vitro and in vivo, Independent of Stemness

Gene Regulation.

Front. Pharmacol. 12:726015. doi: 10.3389/fphar.2021.726015
Experimental and clinical evidence has indicated that the natural product ascorbic acid (AA) is effective in preventing and treating various types of cancers. However, the effect of AA on liver cancer metastasis has not yet been reported. Cancer stem cells (CSCs) play pivotal roles in cancer metastasis. Here, we demonstrated that AA selectively inhibited the viability of both liver cancer cells and CSCs, reduced the formation of cancer cell colonies and CSC spheres, and inhibited tumor growth in vivo. Additionally, AA prevented liver cancer metastasis in a xenotransplantation model without suppressing stemness gene expression in liver CSCs. Further study indicated that AA increased the concentration of $\mathrm{H}_{2} \mathrm{O}_{2}$ and induced apoptosis in liver CSCs. Catalase attenuated the inhibitory effects of AA on liver CSC viability. In conclusion, AA inhibited the viability of liver CSCs and the growth and metastasis of liver cancer cells in vitro and in vivo by increasing the production of $\mathrm{H}_{2} \mathrm{O}_{2}$ and inducing apoptosis. Our findings provide evidence that $\mathrm{AA}$ exerts its anti-liver cancer efficacy in vitro and in vivo, in a manner that is independent of stemness gene regulation.

Keywords: ascorbic acid, cancer stem cells, metastasis, stemness genes, $\mathrm{H}_{2} \mathrm{O}_{2}$, apoptosis

\section{INTRODUCTION}

One of the main causes of cancer-related death is distant metastasis that occurs in cancer patients, and cancer stem cells (CSCs) are an important driving force for cancer metastasis. CSCs, also referred to as tumor-initiating cells, have a stronger tumor-forming ability than somatic or non-tumorigenic cancer cells (Ponti et al., 2005; Ma et al., 2007). CSCs play key roles in the development of metastasis in multiple cancers. In colorectal cancer, $\mathrm{CD} 26^{+} \mathrm{CSCs}$ caused distant metastasis when injected into the mouse cecal wall, while the presence of $\mathrm{CD} 26^{+}$CSCs in primary tumors can predict distant metastasis in cancer patients (Pang et al., 2010). Also, Lgr5 ${ }^{+}$or CD44v6 ${ }^{+}$CSCs are required for the generation of metastatic tumors (Todaro et al., 2014; De Sousa e Melo et al., 2017). In squamous cell carcinoma of the head and neck, it was observed that $\mathrm{BMI}^{+} \mathrm{CSC}$ regulated the invasive growth and cervical lymph node metastasis in a mouse model (Chen D. et al., 2017). A recent study at the singlecell level in breast cancer has shown that early-stage metastatic cells possess a distinct stem-like gene expression signature (Wylie et al., 2015).

Liver cancer is a heterogeneous disease, and liver CSCs play important roles in the development of this disease. Inhibition of ICAM-1, a marker of hepatocellular CSCs, suppresses tumor formation 

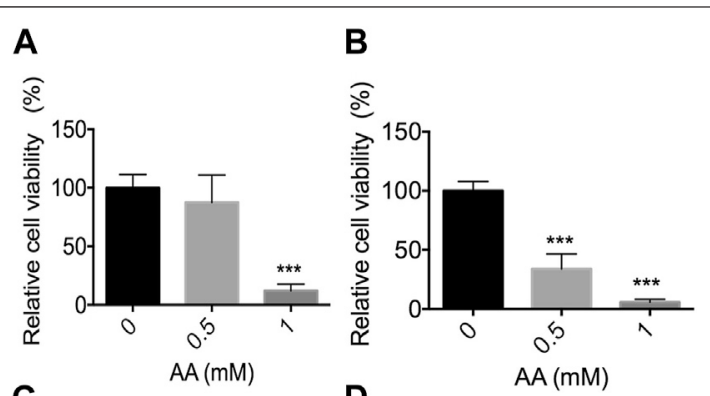

E
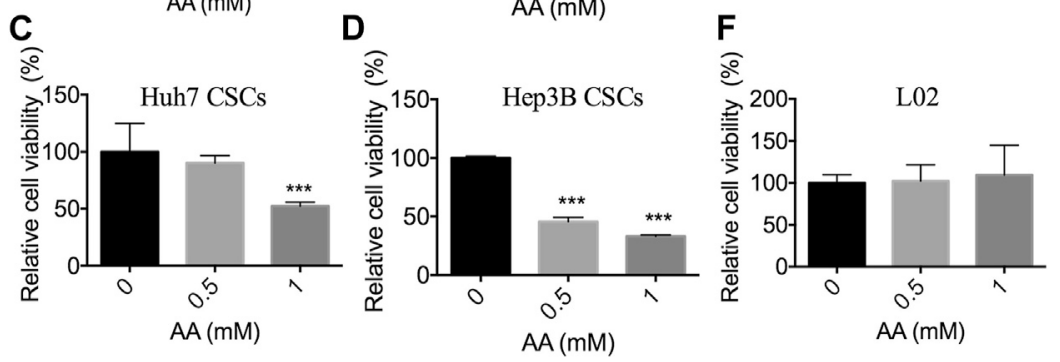

FIGURE 1 | Inhibitory effects of AA on the viability of liver cancer cells in vitro. Cells were treated with AA at the concentration as shown and cell viability was measured by CCK-8 assay. (A) Cell viability of Huh7 cells. (B) Cell viability of Hep3B cells. (C) Cell viability of Huh7 CSCs. (D) Cell viability of Hep3B CSCs. (E) IC50 values of $A A$, values are mean and 95\% confidence. (F) Cell viability of L02 hepatocytes. ${ }^{\star \star \star} p<0.001$.

and metastasis in mice (Liu et al., 2013). All-trans retinoic acid can effectively induce the differentiation of CSCs, and it also enhances the cytotoxicity of cisplatin and increases the inhibition of hepatocellular carcinoma (HCC) cell migration in vitro and metastasis in vivo in combination with cisplatin (Zhang et al., 2013). All of these studies have demonstrated a key role for CSCs in cancer metastasis and suggested that CSCs are a promising target for developing effective therapeutic agents that can be used to treat metastatic cancer.

The natural product ascorbic acid (AA) is an important watersoluble vitamin and is one of the early unorthodox therapies that has long been used in the field of alternative and complementary medicine for cancer treatment, with profound safety and anecdotal efficacy (Du et al., 2010; Chen et al., 2015). Many clinical and laboratory studies have revealed its effects on cancer prevention and treatment. AA inhibits the growth of prostate, ovarian, and pancreatic cancer cells and neuroblastoma cells. (Maramag et al., 1997; Carosio et al., 2007; Chen et al., 2008; Du et al., 2010; Yun et al., 2015; Schoenfeld et al., 2017). Cameron et al. demonstrated in the 1970 s that there was a potential survival benefit for patients who received oral and intravenous administration of AA (Cameron and Pauling, 1976; Cameron and Pauling, 1978). However, two clinical studies performed at the Mayo Clinic have shown no significant difference between oral ascorbate-treated and placebo-treated patients (Moertel and Fleming, 1985; Creagan et al., 1979).

Additional research has shown that oral ingestion of high doses of AA rarely induce a plasma concentration greater than $200 \mu \mathrm{M}$, due to the limited absorption and renal excretion. By contrast, both intravenous (i.v.) and intraperitoneal (i.p.) administration of ascorbate result in pharmacologic serum ascorbate concentrations up to $20 \mathrm{mmol} / \mathrm{L}$ (Reczek and Chandel, 2015; Verrax and Calderon, 2009). Subsequent studies have shown that high-dose intravenous administration of AA alleviates symptoms and prolongs survival in patients with advanced cancer (Cameron and Pauling, 1976; Cameron and Pauling, 1978; Cameron and Campbell, 1974; Padayatty et al., 2006; Raymond et al., 2016). AA also significantly reduces the metastasis of B16FO melanoma cells injected into mice who were deficient in AA and unable to synthesize it (Cha et al., 2013). However, there have been no reports describing the effects of AA on liver cancer metastasis.

With the participation of transition metals (such as copper and iron), a high dose of AA as an electron donor produces extracellular ascorbate anion and $\mathrm{H}_{2} \mathrm{O}_{2}$, which play important roles in AA-induced anticancer activity (Chen et al., 2015). $\mathrm{H}_{2} \mathrm{O}_{2}$, an important reactive oxygen species (ROS), plays numerous roles in cancer cells, where a low concentration of $\mathrm{H}_{2} \mathrm{O}_{2}$ is involved in various signal transduction and cell functions, and a high concentration of $\mathrm{H}_{2} \mathrm{O}_{2}$ causes DNA damage and promotes cell apoptosis. $\mathrm{Du}$ et al. demonstrated that AA decreases the clonogenic survival of pancreatic cancer cell lines, while treatment of cells with $\mathrm{H}_{2} \mathrm{O}_{2}$ scavengers can reverse AA's anticancer activity (Du et al., 2010). Chen et al. reported that AA causes significant cytotoxicity in cancer cells, while glutathione reduces the cytotoxicity by attenuating AA-induced $\mathrm{H}_{2} \mathrm{O}_{2}$ production (Chen et al., 2005; Chen et al., 2011).

In this study, we investigated the inhibitory effects of AA on liver cancer cells and liver CSCs in vitro and in vivo. We found that AA inhibited the growth and metastasis of liver cancer cells and liver CSCs, although AA also increased the expression levels of stemness genes. Further molecular mechanism studies indicated that the increased concentration of $\mathrm{H}_{2} \mathrm{O}_{2}$ and the enhanced apoptosis by AA play vital roles in its efficacy against liver cancer. 


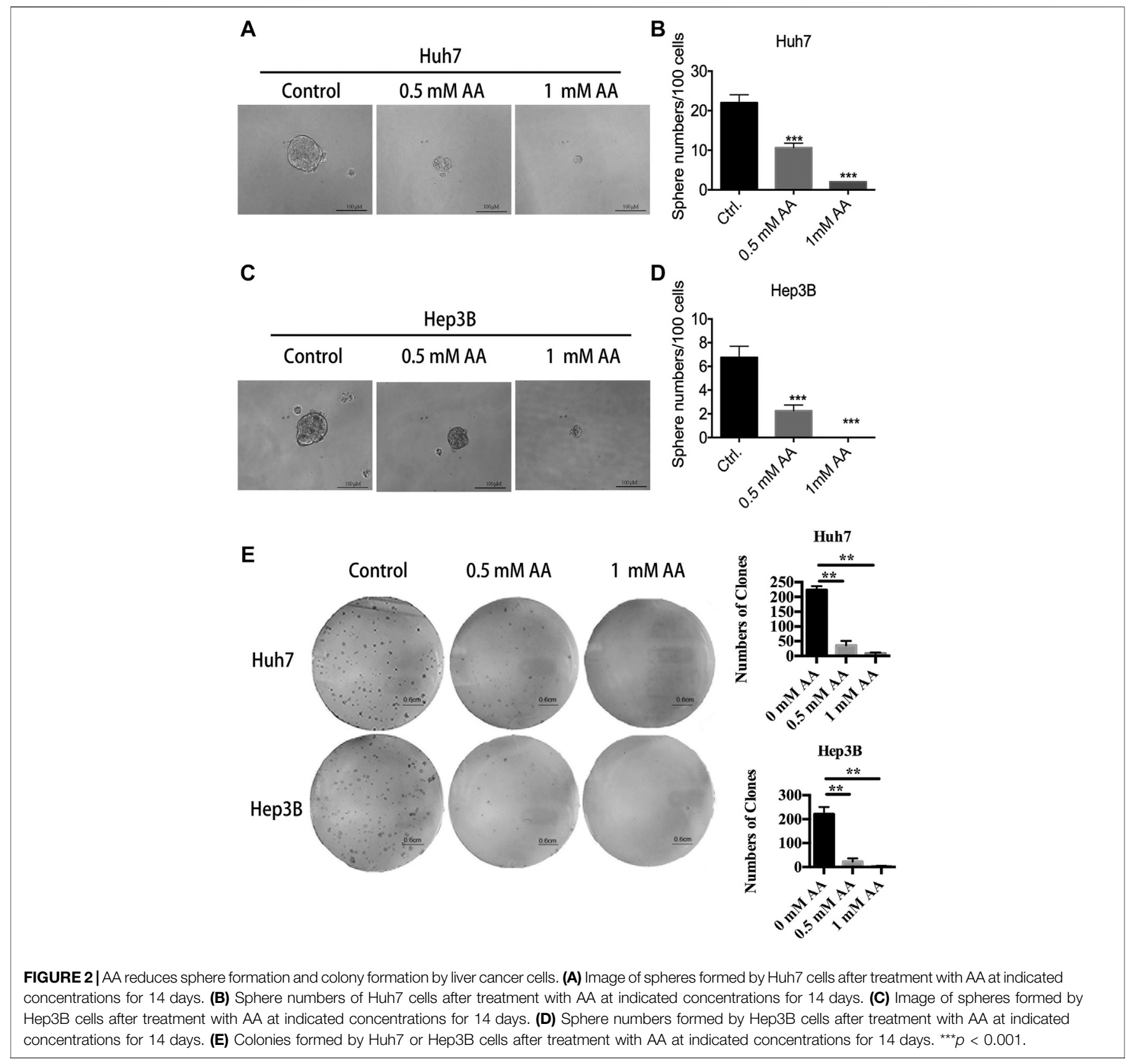

\section{MATERIALS AND METHODS}

\section{Cell Culture}

Human liver cancer cell lines Huh7 and Hep3B and normal human liver cell line L02 cells were cultured in Dulbecco's modified Eagle's medium (DMEM) containing 10\% fetal bovine serum (FBS) and 1\% penicillin/streptomycin. Huh7 and Hep3B CSCs were enriched and maintained on polyHEMA coated plates in serum-free DMEM/Nutrient Mixture F-12 (F-12) medium containing $20 \mathrm{ng} / \mathrm{ml}$ epidermal growth factor (EGF) (236-EG-200, R\&D Systems), $10 \mathrm{ng} / \mathrm{ml}$ fibroblast growth factor (FGF) (233-FB-025, R\&D Systems), and $1 \%$ penicillin/streptomycin (Pang et al., 2010; Li et al., 2015). For preparing poly-HEMA coated plates, 6-well plates were precoated with $1.2 \%(\mathrm{w} / \mathrm{v})$ poly-HEMA (Re et al., 1994).

\section{Detection of Cell Viability}

Cell viability was measured by Cell Counting Kit-8 (CCK-8) (Dojindo Laboratories) according to the user's manual. The cell viability in each group is expressed as the percentage of untreated control cell viability (Wu et al., 2017).

\section{Flow Cytometric Analysis}

To examine the expression of CD133 and CD44, Huh7 and Hep3B stem cells were digested with $0.05 \%$ trypsin. Next, $10^{6}$ cells/100 $\mu \mathrm{l}$ of single cells were resuspended and incubated with PE-labeled CD133 


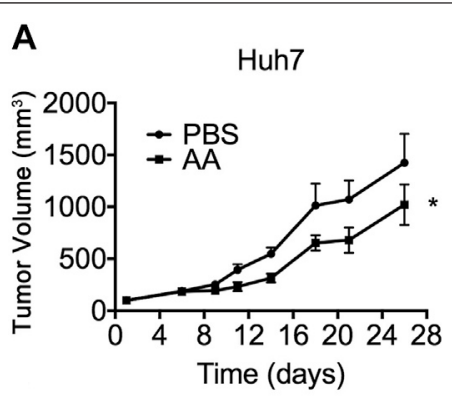

C

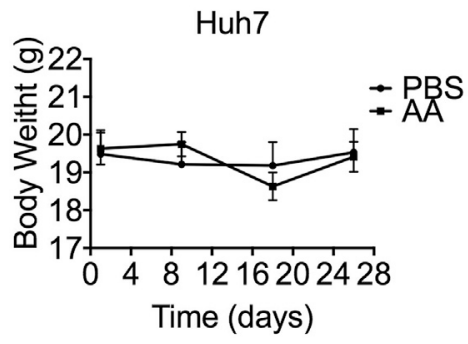

B

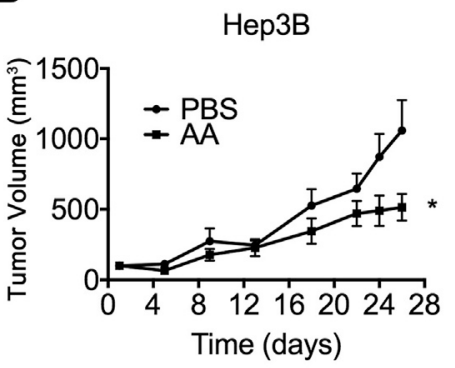

D

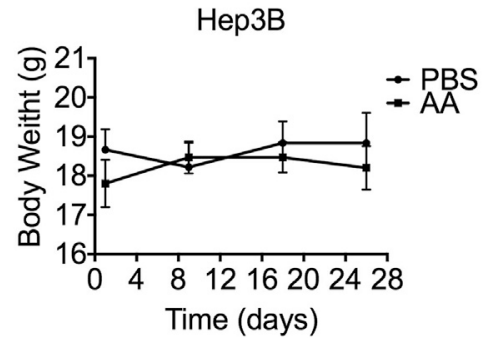

FIGURE 3 |AA suppresses tumor growth in vivo. $2 \times 10^{6}$ Huh7 or Hep3B cells were inoculated subcutaneously into nude mice. 3 weeks later, PBS (control group) or $4 \mathrm{~g} / \mathrm{kg}$ AA was injected intraperitoneally twice daily for 26 days. Tumor volume was measured every 2-3 days and animal body weight was measured every 9 days. (A) Volumes of tumors formed by Huh7 cells. (B) Volumes of tumors formed by Hep3B cells. (D) Body weight of animals engrafted with Huh7 cells. (D) Body weight of animals engrafted with Hep3B cells ${ }^{*} p<0.05$.

(1:50, Miltenyi Biotec) or CD44 (1:50, Miltenyi Biotec) in the dark for $15 \mathrm{~min}$, washed twice with cold phosphate-buffered saline (PBS), resuspended in $400 \mu \mathrm{l} \mathrm{PBS}$, and analyzed using flow cytometry (Becton Dickinson FACS Vantage SE, San Jose, CA, United States).

To analyze cell apoptosis, Huh7 stem cells were digested with $0.05 \%$ trypsin. Then, $1 \times 10^{6}$ single cells were resuspended and mixed with $10 \mu \mathrm{l}$ Annexin V-fluorescein isothiocyanate (FITC, 130097-928, Miltenyi Biotec), incubated in darkness for $15 \mathrm{~min}$, washed with $1 \mathrm{ml} 1 \times$ Annexin V Binding Buffer and resuspended in $500 \mu \mathrm{l}$ $1 \times$ Annexin V Binding Buffer, mixed with propidium iodide (PI) solution, and then analyzed by flow cytometry (Cheng et al., 2017).

\section{RNA Isolation and Quantitative Real-Time PCR}

Total RNA was isolated using a Tissue RNA Kit (R6311-01, Biomiga). RNA ( $1 \mu \mathrm{g}$ ) was reverse-transcribed into cDNA using GoScript Reverse Transcriptase (A5001, Promega). Quantitative real-time PCR was completed using the Power Up SYBR Green Master Mixture (Thermo Fisher) with the StepOne Plus RealTime PCR System (Thermo Fisher), according to a protocol from a previous study (Wu et al., 2017). Specific primers for CD90 and EPCAM were created according to Luo et al. (2015). Specific primers for CD133, OCT4 (POU5F1), NANOG, SOX2, and betaactin were created according to $\mathrm{Ma}$ et al. (2010).

\section{Animal Experiments}

All of the mice were maintained in a pathogen-free facility, and all of the animal experiments were approved by the Committee on the Ethics of Animal Experiments of the Naval Medical University, China. For the animal experiments, 6-week-old female nude BABL/c mice were used, and $2 \times 10^{6}$ Huh7 or Hep3B cells were subcutaneously inoculated into the nude mice (Ma et al., 2018; Yuan et al., 2015). Three weeks later, PBS (control group) or $4 \mathrm{~g} / \mathrm{kg}$ AA was injected intraperitoneally twice daily for 26 days. The tumor volume was calculated as: total volume $=\left(\right.$ length $\times$ width $\left.^{2}\right) / 2($ Naito et al., 1986). Lung and liver tissues were fixed with $4 \%$ polyformaldehyde, and serial sections (four sections per tissue with a $30-\mu \mathrm{m}$ step) were created and stained with hematoxylin and eosin (HE) (Cheng et al., 2017).

\section{Western Blot}

Western blot was completed according to a protocol from a previous study (Wu et al., 2017). Briefly, cells or tissues were lysed with Radioimmunoprecipitation Assay (RIPA) Lysis Buffer (P0013C, Beyotime Biotechnology, China) and centrifuged at 13,000 rpm for $15 \mathrm{~min}$. The supernatant was separated by sodium dodecyl sulfate (SDS)-polyacrylamide gel and transferred to a polyvinylidene difluoride (PVDF) membrane. The membrane was incubated overnight with anti-NANOG (1:500, ab109250, Abcam), anti-SOX2 (1:500, ab92494, Abcam, UK), anti-ALDH1A1 (1:1,000, ab52492, Abcam), or anti- $\beta$-actin $(1: 1,000,3700$, Cell Signaling Technology) primary antibodies, washed with Tris-buffered saline (TBS) containing $0.1 \%$ Tween-20 (TBST) three times, incubated with secondary antibody (926-32210, 1:20,000 for $\beta$-actin and 92632211, 1:5,000 for others, LI-COR, Biosciences), and analyzed with the Odyssey Infrared Imaging System (LI-COR, Biosciences).

\section{Detection of $\mathrm{H}_{2} \mathrm{O}_{2}$}

The $\mathrm{H}_{2} \mathrm{O}_{2}$ concentration was measured using a $\mathrm{H}_{2} \mathrm{O}_{2}$ Assay Kit (S0038, Beyotime Biotechnology, China) according to the user's manual. Simply, $1 \times 10^{6}$ cells were lysed in $200 \mu$ lysis buffer and 

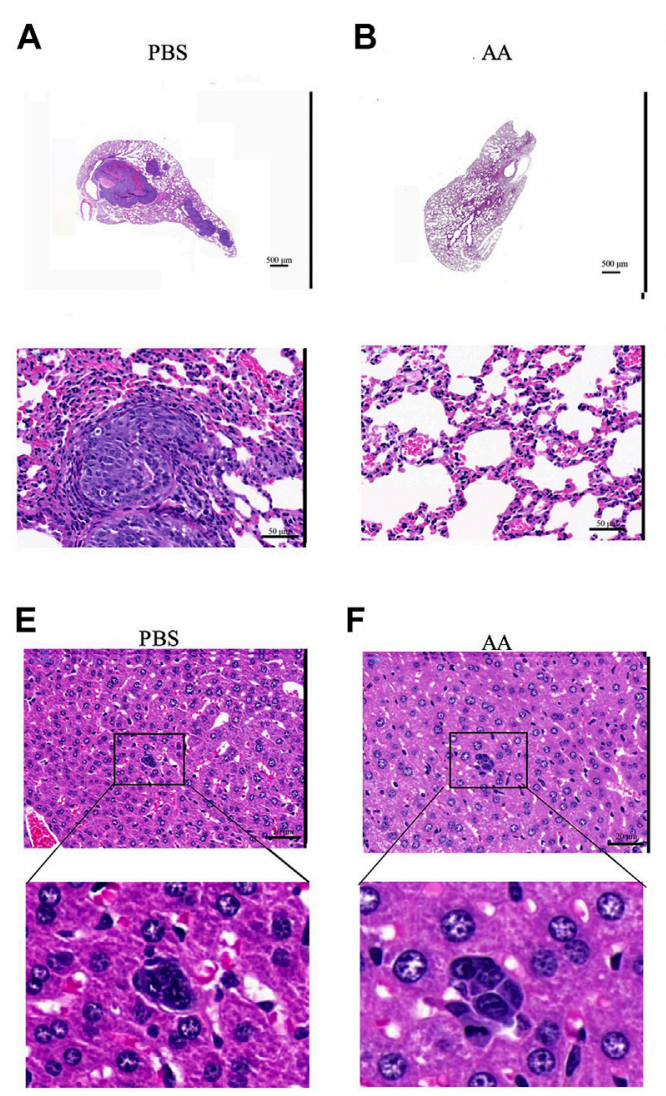

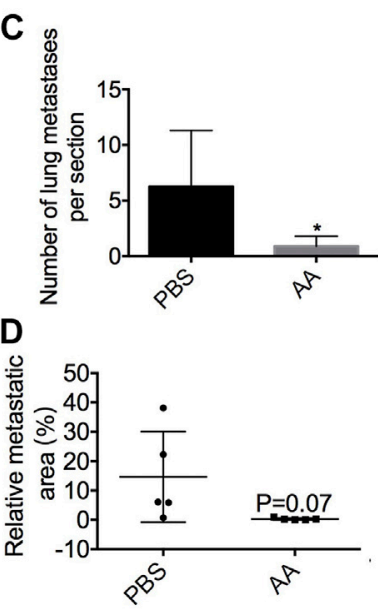

G

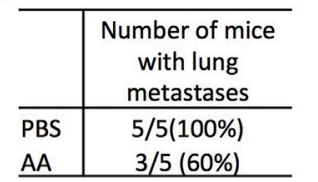

$\mathrm{H}$

\begin{tabular}{l|c}
\hline & $\begin{array}{c}\text { Number of mice } \\
\text { with liver } \\
\text { metastases }\end{array}$ \\
\hline PBS & $4 / 5(80 \%)$ \\
AA & $1 / 5(20 \%)$ \\
\hline
\end{tabular}

FIGURE 4 |AA prevents tumor metastasis in vivo. $2 \times 10^{6}$ Huh7 cells were inoculated subcutaneously into female BALB/c nude mice. After 3 weeks, PBS (control group) or $4 \mathrm{~g} / \mathrm{kg} \mathrm{AA}$ was injected intraperitoneally twice daily. At the end of the experiment, the animals were sacrificed to examine liver and lung metastasis. (A,B) $\mathrm{HE}$ staining of lung section (A: control group, B: AA group; A, B upper: 2x magnification; A, B lower: 40× magnification). (C,D) the number and area ratio of metastatic tumors in each lung section. (E,F) HE staining of liver section. (E: control group, F: AA group; $40 \times$ magnification). (G) Number of mice with lung metastases in each group. (H) Number of mice with liver metastases in each group. ${ }^{*} p<0.05$.

centrifuged for $5 \mathrm{~min}$ at $12,000 \mathrm{rpm}$. Every $50 \mu \mathrm{l}$ of the supernatant was mixed with $100 \mu \mathrm{l}$ of $\mathrm{H}_{2} \mathrm{O}_{2}$ detection reagent and incubated for $30 \mathrm{~min}$ at room temperature. Absorbance was determined at $560 \mathrm{~nm}$ using an Epoch Microplate Spectrophotometer (BioTek). For catalase experiments, catalase was added prior to AA treatment.

\section{Sphere Formation Assay and Colony Formation Assay}

For the sphere formation experiment, cells were digested into single cells with trypsin. Then, 100 cells/well were plated into a 96-well ultra-low attachment plate and cultured for 2 weeks in serum-free DMEM/F-12 medium containing $20 \mathrm{ng} / \mathrm{ml} \mathrm{EGF}$, $10 \mathrm{ng} / \mathrm{ml} \mathrm{FGF}$, and AA $(0,0.5$, or $1 \mathrm{mM})$. The number of spheres was counted and photographed.

For the colony formation experiment, 1,000 cells/well were plated into 6-well plates. The colonies were cultured in DMEM containing $10 \%$ fetal bovine serum, $1 \%$ penicillin/streptomycin, and AA $(0,0.5$, or $1 \mathrm{mM}$ ). The colonies were then stained with $1 \%$ crystal violet.

\section{Statistical Analysis}

Statistical analysis was performed using unpaired $t$ tests when comparing two different groups or one-way ANOVA with
Tukey's multiple comparison tests. IC50 values were calculated using Prism software (GraphPad, San Diego, CA, USA) by nonlinear regression to dose-response curves, and expressed as mean and $95 \%$ confidence intervals (CI). The data are expressed as the mean \pm SEM. $p<0.05$ was considered statistically significant.

\section{RESULTS}

\section{AA Selectively Inhibited the Viability of Liver Cancer Cells and Liver CSCs in vitro}

Two human liver cancer cell lines (Huh7 and Hep3B), the respective CSCs, and a normal human liver cell line L02 were treated with $\mathrm{AA}$ at the concentrations of $0,0.5$, or $1 \mathrm{mM}$, which are easily achievable clinically by intravenous infusion (Chen et al., 2008) (Hoffer et al., 2008). The results showed that AA inhibited the viabilities of liver cancer cells and liver CSCs in a concentrationdependent manner (Figures 1A-D). AA at the concentration of $1 \mathrm{mM}$ decreased the viabilities of Huh7 and Hep3B cells to 12.15 and $5.77 \%$, respectively (Figures 1A,B). For Huh7 and Hep3B CSCs, the viabilities were decreased to 52.37 and $33.04 \%$, respectively, at $1 \mathrm{mM}$ concentration of AA (Figures 1C,D). The IC50 values of AA for Huh7, Hep3B, and Huh7 CSCs and Hep3B CSCs were 0.67, 0.32, 

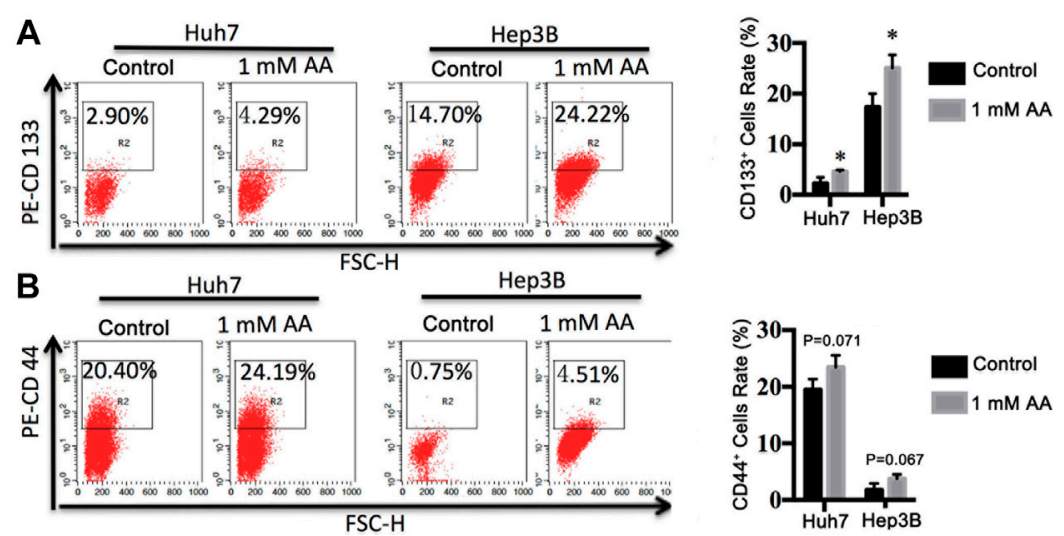

C
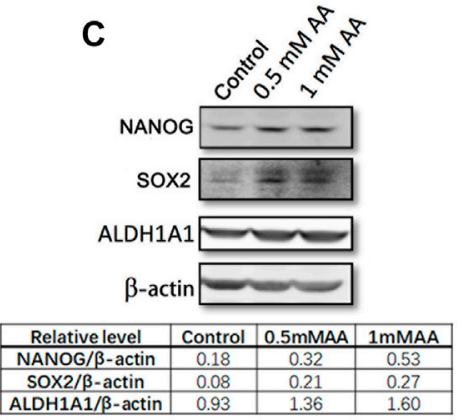

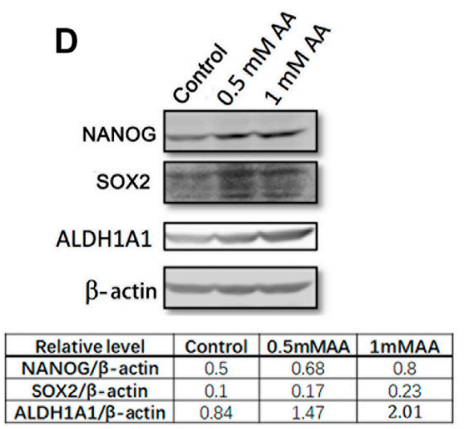

FIGURE 5|AA regulates the expression of stemness genes in liver cancer cells. (A,B) Flow cytometric analysis of the expressions of CD133 and CD44 in Huh7 (A) and Hep3B (B) stem cells treated with different concentrations of AA. (C,D) The protein levels of stemness genes in Huh7 (C) and Hep3B (D) stem cells treated with different concentrations of $A A$.

1.21 , and $0.52 \mathrm{mM}$, respectively (Figure 1E). However, AA did not display significant inhibitory effects on the viability of L02 cells at $0.5 \mathrm{mM}$ or $1 \mathrm{mM}$ concentrations (Figure 1F). Together, these data indicated that AA was responsible for selective inhibitory effects on the viabilities of liver cancer cells and liver CSCs.

\section{AA Inhibits Sphere Formation and Colony Formation in Liver Cancer Cells}

We further examined the effects of AA on sphere formation and colony formation. As shown in Figure 2A, AA treatment reduced the volume of spheres formed by Huh7 cells. The number of spheres larger than $50 \mu \mathrm{m}$ in diameter was markedly decreased in a concentration-dependent manner in AA-treated Huh7 cells (Figure 2B). Twenty-two spheres were formed for every 100 cells in the control group, whereas only two spheres were formed for every 100 cells in the group treated with $1 \mathrm{mM}$ AA. Similar results were obtained for Hep3B cells (Figures 2C,D). As shown in Figure 2E, AA treatment also markedly decreased colony formation in a concentration-dependent manner in Huh7 and Hep3B cell lines. Collectively, our data showed that AA reduced sphere formation and colony formation by liver cancer cells, indicating the inhibitory effects of AA on self-renewal and tumorigenicity of liver cancer cells.

\section{AA Inhibited Liver Tumor Growth in vivo}

We determined the effects of AA on tumor growth in mice bearing Huh7 and Hep3B xenografts. As mentioned above, AA concentrations in human plasma and cells were tightly controlled. With the oral ingestion of high doses of vitamin C, even at 100 times the recommended dietary allowance, the plasma concentration rarely exceeds $200 \mu \mathrm{M}$. Both i.v. and i.p. administration of ascorbate induced pharmacologic serum ascorbate concentrations up to $20 \mathrm{mmol} / \mathrm{L}$. To obtain a pharmacologic serum ascorbate concentration, the i.p. administration method was selected. Compared with the PBS control group, AA treatment significantly suppressed the growth of Huh7 and Hep3B xenograft tumors in vivo (Figures 3A,B) without significantly changing the animal's body weight (Figures 3C,D).

\section{AA Prevents Tumor Metastasis in vivo}

As shown in Figures 4A,B, AA-treated mice developed fewer metastatic lung tumors as compared to the control group. The number of metastatic lung tumors in AA-treated mice was $0.90 \pm$ $0.40(n=5)$, and that in the control mice was $6.25 \pm 2.27(n=5)$ (Figure 4C). The area ratio of metastatic lung tumors in AAtreated mice was $0.29 \pm 0.17(n=5)$, and that in control mice was $14.61 \pm 6.91(n=5)$ (Figure 4D). The metastatic tumors in the livers of either the control or AA groups were small (Figures 4E,F). In the control group, 5 of 5 mice developed metastatic lung tumors, whereas 3 of 5 mice exhibited metastatic lung tumors in the AA-treated group (Figure 4G). Additionally, in the control group, 4 of 5 mice developed metastatic liver tumors, while in the AA-treated group, 1 of 5 mice developed metastatic liver tumors (Figure 4H). In summary, our data demonstrated that AA 

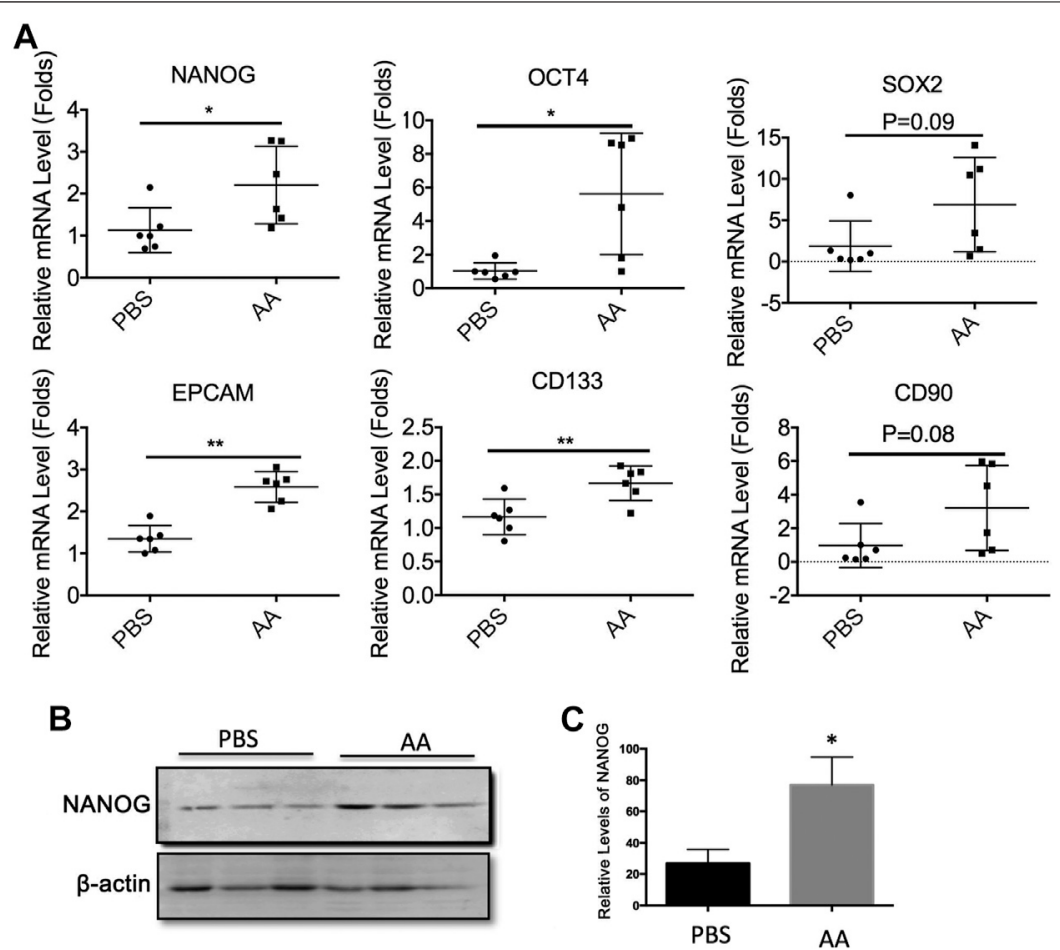

FIGURE 6 | AA regulates the expressions of stemness genes in liver tumors in vivo. $2 \times 10^{6}$ Huh7 cells were inoculated subcutaneously into female BALB/c nude mice. Three weeks later, PBS (control group) or $4 \mathrm{~g} / \mathrm{kg} \mathrm{AA}$ were injected introperitoneally twice a day. At the end of treatment, the animals were sacrificed and tumors were collected for analysis. (A) mRNA levels of stemness genes in tumor tissue. (B,C) Protein levels of NANOG in tumor tissue. ${ }^{*} p<0.05 .{ }^{* \star} p<0.01$.

treatment reduced liver and lung metastasis of liver cancer cells inoculated subcutaneously into nude mice.

\section{AA Upregulated the Expression of Stemness Genes in Liver Cancer Cells and Tumors}

We investigated the effects of AA on the expression of stemness genes. Flow cytometric analysis showed that AA treatment increased $\mathrm{CD}_{133^{+}}$cells and $\mathrm{CD} 44^{+}$cells in both Huh7-and Hep3B-derived stem cells (Figures 5A,B). CD133 antigen was identified as a CSC marker in various cancer types, including liver cancer. CD44, a transmembrane glycoprotein, is also considered as an important liver CSC marker (Zhu et al., 2010; Yang et al., 2008). For Huh7 CSCs, AA at $1 \mathrm{mM}$ increased CD133 ${ }^{+}$cells and CD $44^{+}$cells from 2.90 to $14.70 \%-4.29$ and $24.19 \%$, respectively (Figures 5A,B). For Hep3B CSCs, CD $133^{+}$cells and $\mathrm{CD}_{4} 4^{+}$cells were increased by AA from 20.40 to $0.75 \%-24.22$ and $4.51 \%$, respectively (Figures 5A,B). Western blot analysis showed that the protein levels of embryonic stem cell markers NANOG and SOX2 as well as liver CSC marker ALDH1A1 were increased after treatment with AA in Huh7-and Hep3B-derived stem cells (Figures 5C,D).

We also examined the effects of AA on the expression of stemness genes in liver tumors in vivo. Consistent with the in vitro results, the mRNA expression levels of NANOG, OCT4, SOX2,
EPCAM, CD133, and CD90 were upregulated in the AA-treated tumors (Figure 6A). Also, the protein level of NANOG was increased in the AA-treated group as compared with that of the control group (Figures 6B,C). Collectively, our data showed that AA upregulated the expression of stemness genes in liver cancer cells in vitro and in vivo.

\section{AA Enhanced the Production of $\mathrm{H}_{2} \mathrm{O}_{2}$ and Promoted the Apoptosis of Liver CSCs}

It was reported that $\mathrm{H}_{2} \mathrm{O}_{2}$ plays an important role in AA's anticancer activity (Lennicke et al., 2015; Chaiswing et al., 2018). To determine the role of $\mathrm{H}_{2} \mathrm{O}_{2}$ in the inhibitory effect of AA on liver CSCs, we first evaluated the concentrations of $\mathrm{H}_{2} \mathrm{O}_{2}$ in Huh7-derived CSCs with or without AA treatment. As shown in Figure 7A, AA treatment increased the concentration of $\mathrm{H}_{2} \mathrm{O}_{2}$ in Huh7-derived CSCs. Furthermore, AA increased the protein levels of cleaved poly (ADP-ribose) polymerase (PARP) and cleaved caspase-7 (Figure $7 \mathbf{B}$ ) and promoted cell apoptosis (Figures 7C,D).

Catalase, as a specific $\mathrm{H}_{2} \mathrm{O}_{2}$ scavenger, converts the $\mathrm{ROS} \mathrm{H}_{2} \mathrm{O}_{2}$ to water and oxygen and thereby mitigates the cytotoxic effects of $\mathrm{H}_{2} \mathrm{O}_{2}$. We also found that the addition of catalase reversed the effects of AA on the production of $\mathrm{H}_{2} \mathrm{O}_{2}$ and the cleavage of PARP and caspase-7 (Figures 7E,F). More importantly, the addition of catalase reduced the inhibitory effects of AA on 

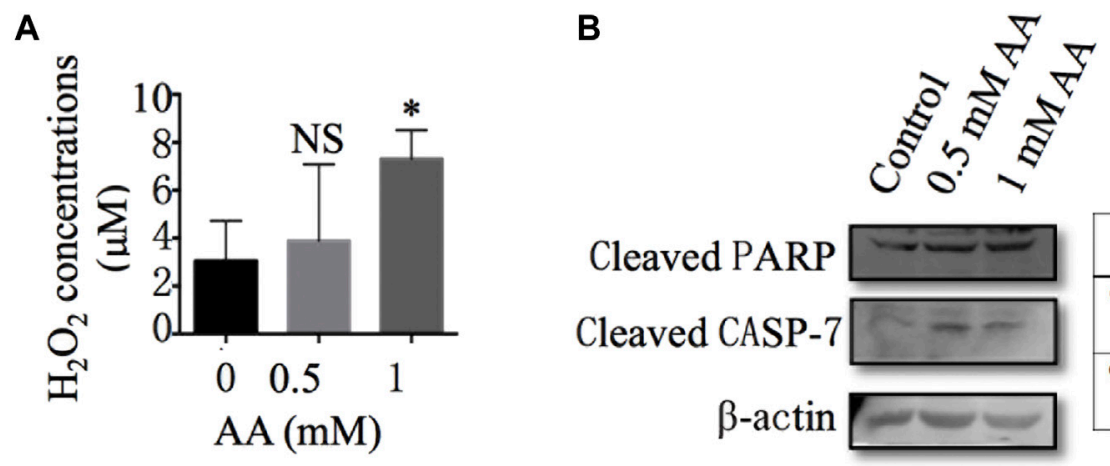

\begin{tabular}{|c|c|c|c|}
\hline Relative level & Control & $\begin{array}{c}\mathbf{0 . 5 m M} \\
\mathbf{A A}\end{array}$ & $\begin{array}{c}\mathbf{1 m M} \\
\mathbf{A A}\end{array}$ \\
\hline $\begin{array}{c}\text { Cleaved PARP/ } \\
\boldsymbol{\beta} \text {-actin }\end{array}$ & 0.6 & 0.96 & 0.45 \\
\hline $\begin{array}{c}\text { Cleaved CASP- } \\
\text { 7/ק-actin }\end{array}$ & 0.06 & 0.12 & 0.14 \\
\hline
\end{tabular}

C
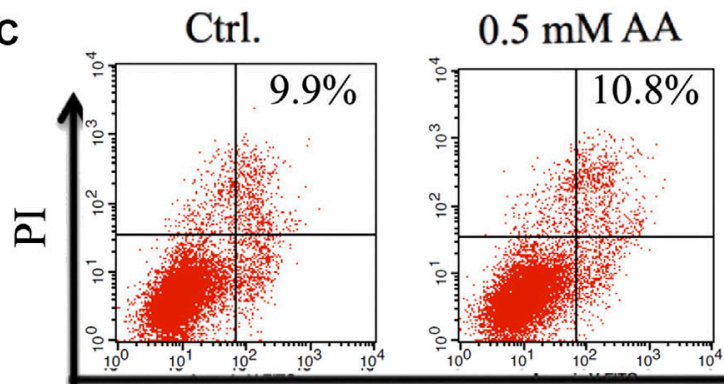

$1 \mathrm{mMAA}$
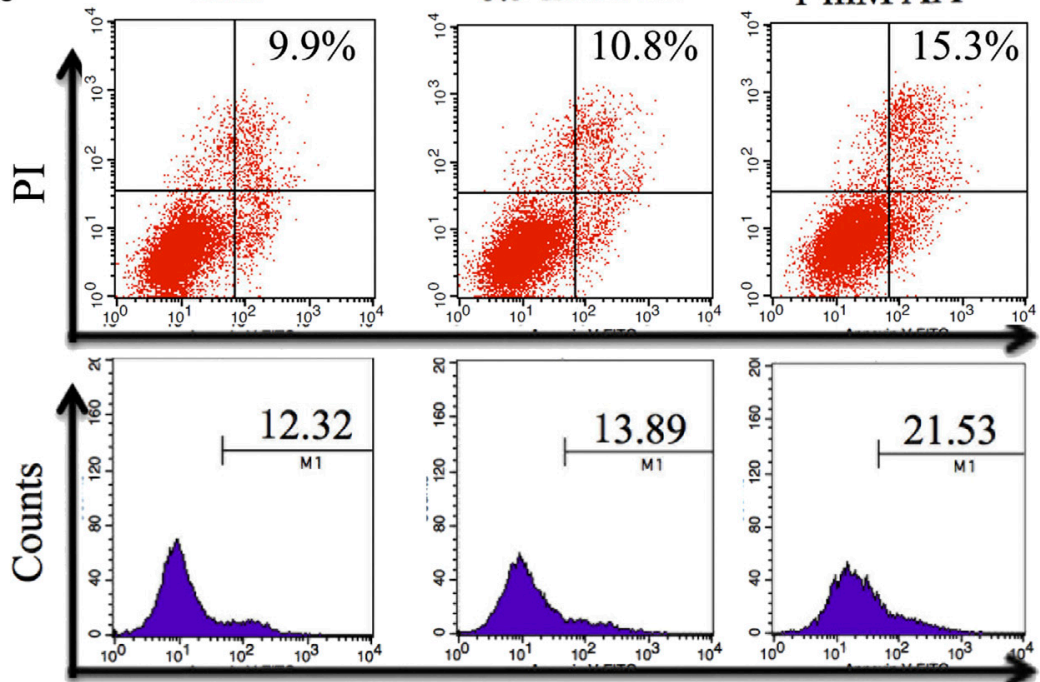

Annexin V-FITC

$\mathbf{E}$
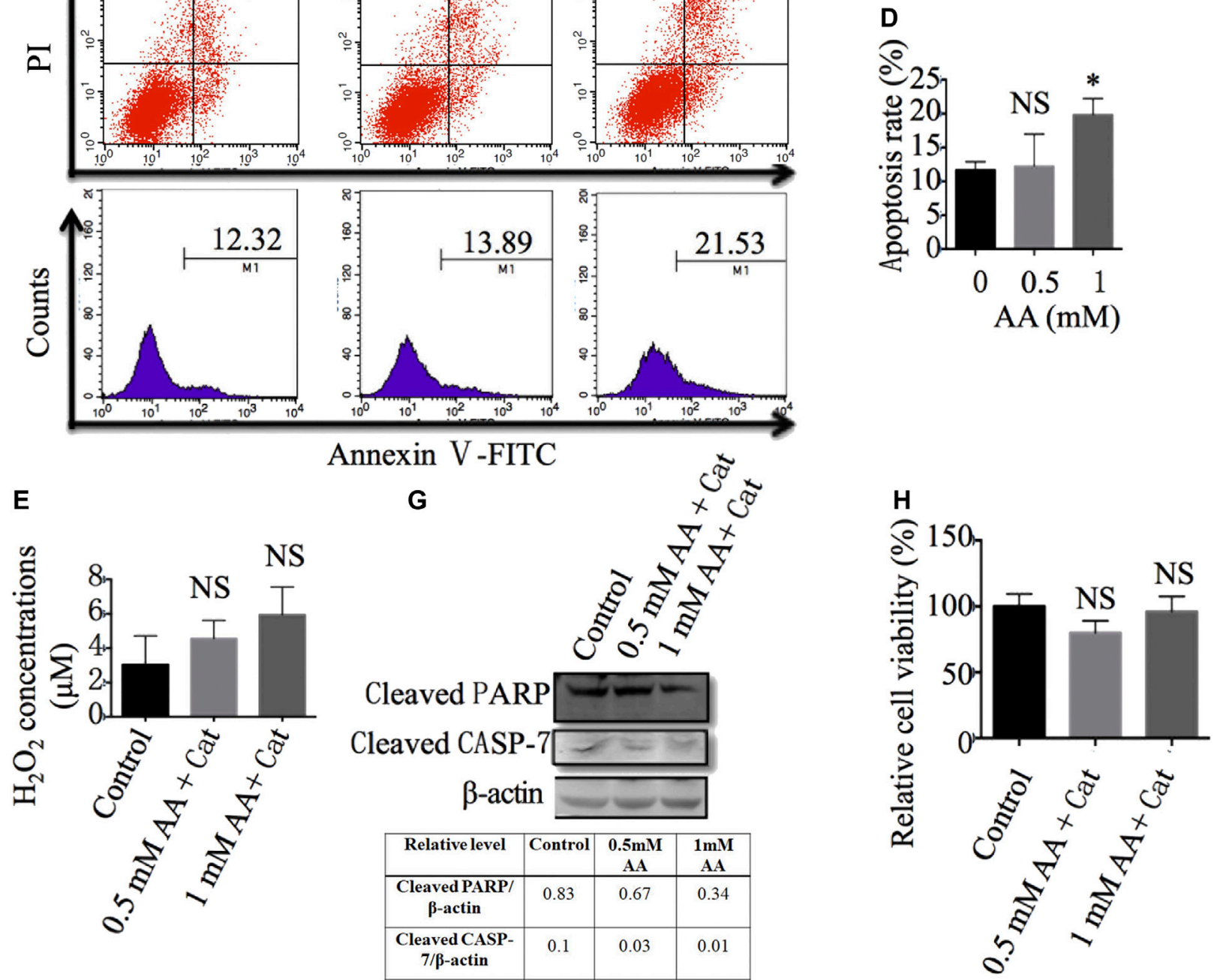

FIGURE 7|AA reduces liver CSC viability via increasing the production of $\mathrm{H} 2 \mathrm{O} 2$ and induction of cell apoptosis. (A) The content of $\mathrm{H}_{2} \mathrm{O}_{2}$ in $\mathrm{Huh}_{7}$ stem cells treated with different concentrations of AA. (B) The protein levels of cleaved PARP and caspase 7 in Huh7 stem cells treated with different concentrations of AA. (C, D) Apoptosis of Huh7 stem cells treated with different concentrations AA. (E) The content of $\mathrm{H}_{2} \mathrm{O}_{2}$ in Huh7 stem cells treated with different concentrations of AA in the presence of $100 \mathrm{\mu g} / \mathrm{ml}$ catalase (Cat: catalase, Sigma -Aldrich). (F) The protein levels of cleaved PARP and caspase 7 in Huh7 stem cells treated with different concentrations of AA in the presence of $100 \mu \mathrm{g} / \mathrm{ml}$ catalase. (G) Viabilities of Huh7 stem cells treated with different concentrations of AA in the presence of $100 \mu \mathrm{g} / \mathrm{ml}$ catalase. ${ }^{*} p<0.05$. 
liver CSC viability (Figure 7G), which was consistent with previous reports describing the dependence of AA's cytotoxicity on the generation of $\mathrm{H}_{2} \mathrm{O}_{2}$ (Du et al., 2010; Chen et al., 2015; Chen et al., 2005). In conclusion, our data indicate that AA exerts its inhibitory effects on liver CSCs through the production of $\mathrm{H}_{2} \mathrm{O}_{2}$ and the promotion of cell apoptosis.

\section{DISCUSSION}

Various factors lead to an increased risk of liver cancer. Among these factors, it has been reported that alcoholic liver disease is the most common cause of HCC, accounting for approximately $30 \%$ of all HCC cases (Morgan et al., 2004). Liver cancer is one of the common causes of cancer-related death. Metastasis and recurrence are the main causes of primary liver cancerassociated mortality. Liver CSCs, possessing a higher migration ability and tumorigenicity, are closely related to metastasis and recurrence of liver cancer. Liver CSCs are considered an important target for liver cancer therapy. For example, WYC209 , a synthetic retinoid, inhibited the proliferation of malignant murine melanoma tumor-repopulating cells and abrogated $87.5 \%$ of lung metastases of melanoma tumor-repopulating cells (Chen et al., 2018).

It was reported that $\mathrm{AA}$ inhibited the growth of various types of cancer, including colorectal cancer cells, neuroblastoma cells, and ovarian cancer cells. However, its effect on liver cancer metastasis has not yet been reported. Consistent with a previous study (Lv et al., 2018), we found that AA inhibited the viability of liver cancer cells without significantly inhibiting the viability of L02 cells, which are normal human hepatocytes. Furthermore, AA significantly attenuated the viability of liver CSCs and reduced the colony formation ability and sphere formation ability of liver cancer cells in vitro, indicating the inhibition by AA on self-renewal and tumorigenicity of liver cancer cells. Because CSCs are involved in important functions in cancer metastasis and AA shows inhibitory effects on liver CSCs, we further examined the effects of AA on liver cancer metastasis. As expected, AA inhibited the metastasis of liver cancer cells to the lung and liver in a subcutaneous xenotransplantation model.

Stemness genes play vital roles in regulating cancer metastasis. In most cases, stemness genes promote cancer metastasis (Lv et al., 2017; Baccelli et al., 2013; Tang et al., 2012; Celià-Terrassa and Kang, 2016). Sox2, a transcription factor involved in the regulation of embryonic development, functions as a novel regulator of cell invasion, migration, and metastasis in several cancer types (Feng and Lu, 2017; Weina and Utikal, 2014). However, it was recently reported that REX1, an embryonic stem cell marker, inhibits liver cancer metastasis, indicating the complex functions of stemness genes in the process of cancer metastasis (Luk et al., 2019). AA regulates the expression of stemness genes, and in human embryonic stem cells, AA caused specific DNA demethylation of 1,847 genes (including the important stem cell genes) (Chung et al., 2010) and also inhibited retinoic acidinduced differentiation of embryonic stem cells ( $\mathrm{Wu}$ et al., 2014). Furthermore, AA alleviated cell aging and increased the production of induced pluripotent stem cells in mice and human cells (Esteban et al., 2010; Wang et al., 2011).

In adult stem cells, AA enhanced the stemness of mouse corneal epithelial stem cells/progenitor cells and promoted the healing of corneal epithelial injury (Chen J. et al., 2017). AA also reduced stemness gene expression in liver cancer ( $\mathrm{LV}$ et al., 2018). Unexpectedly, our data suggested that AA promoted the expression of genes related to cancer stemness. AA increased the production of $\mathrm{CD}_{133^{+}}$and $\mathrm{CD}_{4} 4^{+}$cells and the protein levels of NANOG, SOX2, and ALDH1A1 in vitro and upregulated the mRNA expression levels of NANOG and SOX2 and the protein level of NANOG in Huh7 transplanted tumors. Our data suggest that AA inhibits liver cancer metastasis via a pathway independent of stemness gene regulation. However, the detailed mechanisms of AA-induced expression changes of stemness genes require further study.

Our results indicated that AA did not downregulate the expression of stem genes in liver cancer cells, which implies that other mechanisms are involved in the inhibition of liver cancer metastasis by AA. $\mathrm{H}_{2} \mathrm{O}_{2}$ plays an important role in AA's anticancer activity (Du et al., 2010; Chen et al., 2005; Chen et al., 2011). $\mathrm{H}_{2} \mathrm{O}_{2}$, a key ROS, is involved in cell differentiation, growth, and survival. High levels of $\mathrm{H}_{2} \mathrm{O}_{2}$ can induce cell cycle arrest and apoptosis in cells (Lennicke et al., 2015; Chaiswing et al., 2018). With the participation of transition metals (such as copper and iron), a high dose of $\mathrm{AA}$ as an electron donor produces extracellular ascorbate anion and $\mathrm{H}_{2} \mathrm{O}_{2} \cdot \mathrm{H}_{2} \mathrm{O}_{2}$ is a cell permeant, and its accumulation induces DNA and mitochondrial damage, and apoptosis of tumor cells. The addition of $\mathrm{H}_{2} \mathrm{O}_{2}$ to tumor cells produced the same cell death effect as that caused by AA, while simultaneous use of the antioxidants $\mathrm{N}$-acetylcysteine or catalase with AA inhibited AA-induced tumor cell death. These results further demonstrate the key role of $\mathrm{H}_{2} \mathrm{O}_{2}$ in AA's action upon tumor cells. (Chen et al., 2008; Verrax and Calderon, 2009; Chen et al., 2005; Chen et al., 2007). Normal cells exhibit both catalase and glutathione peroxidase activities, which efficiently detoxify $\mathrm{H}_{2} \mathrm{O}_{2}$. This might be the reason why AA selectively inhibited tumor cells, while it had no toxic effects on normal cells (Chen et al., 2005). We examined the changes in the $\mathrm{H}_{2} \mathrm{O}_{2}$ concentration in liver CSCs treated with AA and found that the $\mathrm{H}_{2} \mathrm{O}_{2}$ concentration was increased after AA treatment. AA treatment also increased the protein levels of apoptotic mediators including cleaved PARP and caspase-7 and enhanced the cell apoptosis of CSCs, while the addition of catalase reduced these effects. These results suggest that AA might induce CSC apoptosis by increasing the intracellular concentration of $\mathrm{H}_{2} \mathrm{O}_{2}$.

In conclusion, AA inhibited the viability of CSCs and prevented liver cancer metastasis without reducing the expression of stemness genes in liver cancer cells. The inhibitory effects of AA on liver CSCs can result from the production of $\mathrm{H}_{2} \mathrm{O}_{2}$ and promotion of cell apoptosis. Our findings provide evidence that supports AA as an effective therapeutic agent for liver cancer metastasis and suggest that additional effects other than inhibition of stemness genes may be considered during later evaluation of the effects of AA on CSCs and cancer metastasis. 


\section{DATA AVAILABILITY STATEMENT}

The original contributions presented in the study are included in the article/Supplementary Material, further inquiries can be directed to the corresponding authors.

\section{ETHICS STATEMENT}

The animal study was reviewed and approved by the Committee on the Ethics of Animal Experiments of the Naval Medical University.

\section{REFERENCES}

Baccelli, I., Schneeweiss, A., Riethdorf, S., Stenzinger, A., Schillert, A., Vogel, V., et al. (2013). Identification of a Population of Blood Circulating Tumor Cells from Breast Cancer Patients that Initiates Metastasis in a Xenograft Assay. Nat. Biotechnol. 31, 539-544. doi:10.1038/nbt.2576

Cameron, E., and Campbell, A. (1974). The Orthomolecular Treatment of Cancer II. Clinical Trial of High-Dose Ascorbic Acid Supplements in Advanced Human Cancer. Chem. Biol. Interact. 9, 285-315. doi:10.1016/0009-2797(74) 90019-2

Cameron, E., and Pauling, L. (1976). Supplemental Ascorbate in the Supportive Treatment of Cancer: Prolongation of Survival Times in Terminal Human Cancer. Proc. Natl. Acad. Sci. 73, 3685-3689. doi:10.1073/pnas.73.10.3685

Cameron, E., and Pauling, L. (1978). Supplemental Ascorbate in the Supportive Treatment of Cancer: Reevaluation of Prolongation of Survival Times in Terminal Human Cancer*. Proc. Natl. Acad. Sci. 75, 4538-4542. doi:10.1073/pnas.73.10.3685

Carosio, R., Zuccari, G., Orienti, I., Mangraviti, S., and Montaldo, P. G. (2007). Sodium Ascorbate Induces Apoptosis in Neuroblastoma Cell Lines by Interfering with Iron Uptake. Mol. Cancer 6, 55. doi:10.1186/1476-4598-6-55

Celià-Terrassa, T., and Kang, Y. (2016). Distinctive Properties of MetastasisInitiating Cells. Genes Dev. 30, 892-908. doi:10.1101/gad.277681.116

Cha, J., Roomi, M. W., Ivanov, V., Kalinovsky, T., Niedzwiecki, A., and Rath, M. (2013). Ascorbate Supplementation Inhibits Growth and Metastasisof B16FO Melanoma and 4T1 Breast Cancer Cellsin Vitamin C-Deficient Mice. Int. J. Oncol. 42, 55-64. doi:10.3892/ijo.2012.1712

Chaiswing, L., Clair, W. H. S., and Clair, D. K. S. (2018). Redox Paradox: A Novel Approach to Therapeutics-Resistant Cancer. Antioxid. Redox Signal 29, 1237-1272. doi:10.1089/ars.2017.7485

Chen, D., Wu, M., Li, Y., Chang, I., Yuan, Q., Ekimyan-Salvo, M., et al. (2017a). Targeting BMI1+Cancer Stem Cells Overcomes Chemoresistance and Inhibits Metastases in Squamous Cell Carcinoma. Cell Stem Cell 20, 621-634. e6. doi:10.1016/j.stem.2017.02.003

Chen, J., Cao, X., An, Q., Zhang, Y., Li, K., Yao, W., et al. (2018). Inhibition of Cancer Stem Cell like Cells by a Synthetic Retinoid. Nat. Commun. 9, 1-10. doi:10.1038/s41467-018-03877-7

Chen, J., Lan, J., Liu, D., Backman, L. J., Zhang, W., and Zhou, Q. (2017b). Ascorbic Acid Promotes the Stemness of Corneal Epithelial Stem/Progenitor Cells and Accelerates Epithelial Wound Healing in the Cornea. Stem Cell Transl. Med. 6, 1356-1365. doi:10.5966/sctm.2013-0122

Chen, P., Stone, J., Sullivan, G., Drisko, J. A., and Chen, Q. (2011). Anti-cancer Effect of Pharmacologic Ascorbate and its Interaction with Supplementary Parenteral Glutathione in Preclinical Cancer Models. Free Radic. Biol. Med. 51, 681-687. doi:10.1016/j.freeradbiomed.2011.05.031

Chen, Q., Espey, M. G., Krishna, M. C., Mitchell, J. B., Corpe, C. P., Buettner, G. R., et al. (2005). Pharmacologic Ascorbic Acid Concentrations Selectively Kill Cancer Cells: Action as a Pro-drug to Deliver Hydrogen Peroxide to Tissues. Proc. Natl. Acad. Sci. U. S. A. 102, 13604-13609. doi:10.1073/pnas.0506390102

Chen, Q., Espey, M. G., Sun, A. Y., Lee, J. H., Krishna, M. C., Shacter, E., et al. (2007). Ascorbate in Pharmacologic Concentrations Selectively Generates

\section{AUTHOR CONTRIBUTIONS}

JW, JZ, LF, YL, and HWZ designed and conducted experiments, and wrote the manuscript. XK helped study design and interpretation of data. CL, HJ organized, conceived, and supervised the study. All authors read and approved the manuscript.

\section{FUNDING}

The work was supported by National Natural Science Foundation of China (81903510), National Major Project of China (2019ZX09201004-003-010).

Ascorbate Radical and Hydrogen Peroxide in Extracellular Fluid In Vivo. Proc. Natl. Acad. Sci. U. S. A. 104, 8749-8754. doi:10.1073/pnas.0702854104

Chen, Q., Espey, M. G., Sun, A. Y., Pooput, C., Kirk, K. L., Krishna, M. C., et al. (2008). Pharmacologic Doses of Ascorbate Act as a Prooxidant and Decrease Growth of Aggressive Tumor Xenografts in Mice. Proc. Natl. Acad. Sci. 105, 11105-11109. doi:10.1073/pnas.0804226105

Chen, Q., Polireddy, K., Chen, P., and Dong, R. (2015). The Unpaved Journey of Vitamin C in Cancer Treatment. Can. J. Physiol. Pharmacol. 93, 1055-1063. doi:10.1139/cjpp-2014-0509

Cheng, Z., Yuan, X., Qu, Y., Li, X., Wu, G., Li, C., et al. (2017). Bruceine D Inhibits Hepatocellular Carcinoma Growth by Targeting $\beta$-catenin/jagged1 Pathways. Cancer Lett. 403, 195-205. doi:10.1016/j.canlet.2017.06.014

Chung, T. L., Brena, R. M., Kolle, G., Grimmond, S. M., Berman, B. P., Laird, P. W., et al. (2010). Vitamin C Promotes Widespread yet Specific DNA Demethylation of the Epigenome in Human Embryonic Stem Cells. Stem Cells 28, 1848-1855. doi:10.1002/stem.493

Creagan, E. T., Moertel, C. G., O’Fallon, J. R., Schutt, A. J., O’Connell, M. J., Rubin, J., et al. (1979). Failure of High-Dose Vitamin C (Ascorbic Acid) Therapy to Benefit Patients with Advanced Cancer. A Controlled Trial. N. Engl. J. Med. 301, 687-690. doi:10.1056/NEJM198603063141003

De Sousa e Melo, F., Kurtova, A. V., Harnoss, J. M., Kljavin, N., Hoeck, J. D., Hung, J., et al. (2017). A Distinct Role for Lgr5 + Stem Cells in Primary and Metastatic colon Cancer. Nature 543, 676-680. doi:10.1038/nature21713

Du, J., Martin, S. M., Levine, M., Wagner, B. A., Buettner, G. R., Wang, S. H., et al. (2010). Mechanisms of Ascorbate-Induced Cytotoxicity in Pancreatic Cancer. Clin. Cancer Res. 16, 509-520. doi:10.1158/1078-0432.CCR-09-1713

Esteban, M. A., Wang, T., Qin, B., Yang, J., Qin, D., Cai, J., et al. (2010). Vitamin C Enhances the Generation of Mouse and Human Induced Pluripotent Stem Cells. Cell Stem Cell 6, 71-79. doi:10.1016/j.stem.2009.12.001

Feng, X., and Lu, M. (2017). Expression of Sex-Determining Region Y-Box Protein 2 in Breast Cancer and its Clinical Significance. Saudi Med. J. 38, 685-690. doi:10.15537/smj.2017.7.19372

Hoffer, L. J., Levine, M., Assouline, S., Melnychuk, D., Padayatty, S. J., Rosadiuk, K., et al. (2008). Phase I Clinical Trial of i.V. Ascorbic Acid in Advanced Malignancy. Ann. Oncol. 19, 1969-1974. doi:10.1093/annonc/mdn377

Lennicke, C., Rahn, J., Lichtenfels, R., Wessjohann, L. A., and Seliger, B. (2015). Hydrogen Peroxide - Production, Fate and Role in Redox Signaling of Tumor Cells. Cell Commun. Signal. 13, 1-19. doi:10.1186/s12964-015-0118-6

Li, Y., Rogoff, H. a., Keates, S., Gao, Y., Murikipudi, S., Mikule, K., et al. (2015). Suppression of Cancer Relapse and Metastasis by Inhibiting Cancer Stemness. Proc. Natl. Acad. Sci. U. S. A. 112, 1839-1844. doi:10.1073/pnas.1424171112

Liu, S., Li, N., Yu, X., Xiao, X., Cheng, K., Hu, J., et al. (2013). Expression of Intercellular Adhesion Molecule 1 by Hepatocellular Carcinoma Stem Cells and Circulating Tumor Cells. Gastroenterology 144, 1031-1041. doi:10.1053/ j.gastro.2013.01.046

Luk, S. T., Ng, K., Zhou, L., Tong, M., Wong, T., Yu, H., et al. (2019). Deficiency in Embryonic Stem Cell Marker REX1 Activates MKK6-dependent P38 MAPK Signaling to Drive Hepatocarcinogenesis. Hepatology 72, 183-197. doi:10.1002/hep.31020

Luo, Z. L., Cheng, S. Q., Shi, J., Zhang, H. L., Zhang, C. Z., Chen, H. Y., et al. (2015). A Splicing Variant of Merlin Promotes Metastasis in Hepatocellular Carcinoma. Nat. Commun. 6, 8457. doi:10.1038/ncomms9457 
Lv, C., Li, F., Li, X., Tian, Y., Zhang, Y., Sheng, X., et al. (2017). MiR-31 Promotes Mammary Stem Cell Expansion and Breast Tumorigenesis by Suppressing Wnt Signaling Antagonists. Nat. Commun. 8, 1036-1053. doi:10.1038/s41467-01701059-5

Lv, H., Wang, C., Fang, T., Li, T., Lv, G., Han, Q., et al. (2018). Vitamin C Preferentially Kills Cancer Stem Cells in Hepatocellular Carcinoma via SVCT2. Npj Precis. Oncol 2, 1. doi:10.1038/s41698-017-0044-8

Ma, C., Han, M., Heinrich, B., Fu, Q., Zhang, Q., Sandhu, M., et al. (2018). Gut Microbiome-Mediated Bile Acid Metabolism Regulates Liver Cancer via NKT Cells. Science 360, eaan5931. doi:10.1126/science.aan5931

Ma, S., Chan, K. W., Hu, L., Lee, T. K. W., Wo, J. Y. H., Ng, I. O. L., et al. (2007). Identification and Characterization of Tumorigenic Liver Cancer Stem/Progenitor Cells. Gastroenterology 132, 2542-2556. doi:10.1053/j.gastro.2007.04.025

Ma, S., Tang, K. H., Chan, Y. P., Lee, T. K., Kwan, P. S., Castilho, A., et al. (2010). MiR-130b Promotes CD133+ Liver Tumor-Initiating Cell Growth and SelfRenewal via Tumor Protein 53-Induced Nuclear Protein 1. Cell Stem Cell 7, 694-707. doi:10.1016/j.stem.2010.11.010

Maramag, C., Menon, M., Balaji, K. C., Reddy, P. G., and Laxmanan, S. (1997). Effect of Vitamin C on Prostate Cancer Cells In Vitro: Effect on Cell Number, Viability, and DNA Synthesis. Prostate 32, 188-195. doi:10.1002/(SICI)10970045(19970801)32:3<188:AID-PROS5>3.0.CO;2-H

Moertel, C., and Fleming, T. (1985). High-dose Vitamin C versus Placebo in the Treatment of Patients with Advanced Cancer Who Have Had No Prior Chemotherapy: a Randomized Double-Blind Comparison. New Engl. J. 312, 137-141. doi:10.1056/NEJM198501173120301

Morgan, T. R., Mandayam, S., and Jamal, M. M. (2004). Alcohol and Hepatocellular Carcinoma. Gastroenterology 127, 87-96. doi:10.1053/j.gastro.2004.09.020

Naito, S., von Eschenbach, A. C., and Fidler, I. J. (1986). Growth and Metastasis of Tumor Cells Isolated from a Human Renal Cell Carcinoma Implanted into Different Organs of Nude Mice. Cancer Res. 46, 4109-4115.

Padayatty, S. J., Riordan, H. D., Hewitt, S. M., Katz, A., Hoffer, L. J., and Levine, M. (2006). Intravenously Administered Vitamin $C$ as Cancer Therapy: Three Cases. Cmaj 174, 937-942. doi:10.1503/cmaj.050346

Pang, R., Law, W. L., Chu, A. C. Y., Poon, J. T., Lam, C. S. C., Chow, A. K. M., et al. (2010). A Subpopulation of CD26 + Cancer Stem Cells with Metastatic Capacity in Human Colorectal Cancer. Cell Stem Cell 6, 603-615. doi:10.1016/j.stem.2010.04.001

Ponti, D., Costa, A., Zaffaroni, N., Pratesi, G., Petrangolini, G., Coradini, D., et al. (2005). Isolation and In Vitro Propagation of Tumorigenic Breast Cancer Cells with Stem/Progenitor Cell Properties. Cancer Res. 65, 5506-5511. doi:10.1158/ 0008-5472.CAN-05-0626

Raymond, Y. C. F., Glenda, C. S. L., and Meng, L. K. (2016). Effects of High Doses of Vitamin C on Cancer Patients in Singapore: Nine Cases. Integr. Cancer Ther. 15, 197-204. doi:10.1177/1534735415622010

Re, F., Zanetti, A., Sironi, M., Polentarutti, N., Lanfrancone, L., Dejana, E., et al. (1994). Inhibition of anchorage-dependent Cell Spreading Triggers Apoptosis in Cultured Human Endothelial Cells. J. Cel Biol. 127, 537-546. doi:10.1083/jcb.127.2.537

Reczek, C. R., and Chandel, N. S. (2015). Revisiting Vitamin C and Cancer. Science 350, 1317-1318. doi:10.1126/science.aad8671

Schoenfeld, J. D., Sibenaller, Z. A., Mapuskar, K. A., Wagner, B. A., CramerMorales, K. L., Furqan, M., et al. (2017). O2- and H2O2-Mediated Disruption of Fe Metabolism Causes the Differential Susceptibility of NSCLC and GBM Cancer Cells to Pharmacological Ascorbate. Cancer Cell 31, 487-500. doi:10.1016/j.ccell.2017.02.018

Tang, K. H., Ma, S., Lee, T. K., Chan, Y. P., Kwan, P. S., Tong, C. M., et al. (2012). CD133 + Liver Tumor-Initiating Cells Promote Tumor Angiogenesis, Growth, and Self-Renewal through neurotensin/interleukin-8/CXCL1 Signaling. Hepatology 55, 807-820. doi:10.1002/hep.24739
Todaro, M., Gaggianesi, M., Catalano, V., Benfante, A., Iovino, F., Biffoni, M., et al. (2014). CD44v6 Is a Marker of Constitutive and Reprogrammed Cancer Stem Cells Driving colon Cancer Metastasis. Cell Stem Cell 14, 342-356. doi:10.1016/ j.stem.2014.01.009

Verrax, J., and Calderon, P. B. (2009). Pharmacologic Concentrations of Ascorbate Are Achieved by Parenteral Administration and Exhibit Antitumoral Effects. Free Radic. Biol. Med. 47, 32-40. doi:10.1016/j.freeradbiomed.2009.02.016

Wang, T., Chen, K., Zeng, X., Yang, J., Wu, Y., Shi, X., et al. (2011). The Histone Demethylases Jhdmla/1b Enhance Somatic Cell Reprogramming in a Vitamin-Cdependent Manner. Cell Stem Cell 9, 575-587. doi:10.1016/j.stem.2011.10.005

Weina, K., and Utikal, J. (2014). SOX2 and Cancer: Current Research and its Implications in the Clinic. Clin. Transl. Med. 3, 19. doi:10.1186/2001-1326-3-19

Wu, G., Zhu, L., Yuan, X., Chen, H., Xiong, R., Zhang, S., et al. (2017). Britanin Ameliorates Cerebral Ischemia-Reperfusion Injury by Inducing the Nrf2 Protective Pathway. Antioxid. Redox Signal 27, 754-768. doi:10.1089/ars.2016.6885

Wu, H., Wu, Y., Ai, Z., Yang, L., Gao, Y., Du, J., et al. (2014). Vitamin C Enhances Nanog Expression via Activation of the JAK/STAT Signaling Pathway. Stem Cells 32, 166-176. doi:10.1002/stem.1523

Wylie, B. J., Singh, M. P., Coull, B. A., Quinn, A., Yeboah-, K., Sabin, L., et al. (2015). Single-cell Analysis Reveals a Stem-Cell Program in Human Metastatic Breast Cancer Cells. Nature 526, 131-135. doi:10.1038/nature15260

Yang, Z. F., Ho, D. W., Ng, M. N., Lau, C. K., Yu, W. C., Ngai, P., et al. (2008). Significance of CD90+ Cancer Stem Cells in Human Liver Cancer. Cancer Cell 13, 153-166. doi:10.1016/j.ccr.2008.01.013

Yuan, D., Chen, L., Li, M., Xia, H., Zhang, Y., Chen, T., et al. (2015). Isolation and Characterization of Circulating Tumor Cells from Human Gastric Cancer Patients. J. Cancer Res. Clin. Oncol. 141, 647-660. doi:10.1007/s00432-0141814-0

Yun, J., Mullarky, E., Lu, C., Kaitlyn, N., Kavalier, A., Rivera, K., et al. (2015). Vitamin C Selectively Kills KRAS and BRAF Mutant Colorectal Cancer Cells by Targeting GAPDH. Science 350, 1391-1396. doi:10.1126/ science.aaa5004

Zhang, Y., Guan, D., Shi, J., Gao, H., Li, J., Zhao, J., et al. (2013). All-trans Retinoic Acid Potentiates the Chemotherapeutic Effect of Cisplatin by Inducing Differentiation of Tumor Initiating Cells in Liver Cancer. J. Hepatol. 59, 1255-1263. doi:10.1016/j.jhep.2013.07.009

Zhu, Z., Hao, X., Yan, M., Yao, M., Ge, C., Gu, J., et al. (2010). Cancer Stem/ progenitor Cells Are Highly Enriched in CD133+CD44+ Population in Hepatocellular Carcinoma. Int. J. Cancer 126, 2067-2078. doi:10.1002/ijc.24868

Conflict of Interest: The authors declare that the research was conducted in the absence of any commercial or financial relationships that could be construed as a potential conflict of interest.

Publisher's Note: All claims expressed in this article are solely those of the authors and do not necessarily represent those of their affiliated organizations, or those of the publisher, the editors and the reviewers. Any product that may be evaluated in this article, or claim that may be made by its manufacturer, is not guaranteed or endorsed by the publisher.

Copyright $\odot 2021$ Wan, Zhou, Fu, Li, Zeng, Xu, Lv and Jin. This is an open-access article distributed under the terms of the Creative Commons Attribution License (CC $B Y$ ). The use, distribution or reproduction in other forums is permitted, provided the original author(s) and the copyright owner(s) are credited and that the original publication in this journal is cited, in accordance with accepted academic practice. No use, distribution or reproduction is permitted which does not comply with these terms. 